\title{
Phosphite-Based Nutrients Impact Mineral Elements, Bitter Pit, and Fruit Quality Attributes of 'Braeburn' Apple
}

\author{
Esmaeil Fallahi* \\ Department of Plant Sciences, Parma Research and Extension Center, University of Idaho, USA
}

\begin{abstract}
Preharvest nutrient applications have major impacts on apple (Malus domestica Bork) tree mineral status, productivity, and fruit quality attributes. Despite the wide use of calcium chloride $\left(\mathrm{CaCl}_{2}\right)$ for improving apple fruit quality attributes particularly bitter pit, application of amino acid, polyamine and phosphite-based nutrients (Sysstem series) have become popular in the past decade. Susceptibility to bitter pit disorder varies greatly in different apples, among which 'Braeburn' is an extremely susceptible cultivars to this disorder. Thus, the impacts of Sysstem nutrients on leaf and fruit mineral status in one year and yield and fruit bitter pit and quality attributes in two years were compared with those of commercial "Grower's nutrients" in 'Braeburn' apple (Malus domestica Bork), each year according to a randomized complete block design. Trees receiving Sysstem nutrients had lower leaf nitrogen $(N)$, phosphorus $(P)$, potassium $(K)$ and boron $(B)$ but slightly higher leaf magnesium (Mg), iron ( $\mathrm{Fe}$ ) and zinc $(\mathrm{Zn})$ than those with Grower's nutrients. Sysstem nutrients applications reduced and improved fruit $\mathrm{N} / \mathrm{Ca}, \mathrm{K} / \mathrm{Ca},(\mathrm{K}+\mathrm{Mg}) / \mathrm{Ca}$ ratios over Grower nutrients. The improvement of mineral concentrations and certain mineral ratios resulted in better color, higher soluble solids concentration, more advanced starch hydrolysis, and lower bitter pit than those receiving Grower's nutrients. Sysstem nutrients drastic reduction in the bitter pit disorder was the main advantage of this nutrient regime over traditional Grower nutrient applications in this study.
\end{abstract}

\section{Keywords}

Bitter pit, Calcium (ca), Malus domestica, Mineral nutrition partitioning, Storage

\section{Introduction}

\section{'Braeburn' apple and its challenges}

'Braeburn' apple has gained popularity among consumers in the past decade, while it is sensitive to bitter pit disorder. However, limited information is available on the effects of foliar nutrients on 'Braeburn' apple yield and fruit quality attributes. The physiological and biochemical roles of calcium $(\mathrm{Ca})$, nitrogen $(\mathrm{N})$, potassium $(\mathrm{K})$, and magnesium $(\mathrm{Mg})$ on postharvest physiology of pome fruit have been extensively studied, because these elements are known to be more involved in various fruit quality attributes, particularly bitter pit incidence than other mineral elements.

\section{Role of calcium}

DeLong, et al. [1], Smock, et al. [2], Garman and Mathis, et al. [3] were among the first researchers who found a negative correlation between fruit $\mathrm{Ca}$ concentration and the incidence of bitter pit. Fruit $\mathrm{Ca}$ concentration and ratios of other nutrients to $\mathrm{Ca}$ in the fruit tissue are possibly the most important factors affecting bitter pit formation and associate with regards to crop losses [4-16]. Smock and Van Doren, et al. [17] described the first sign of bitter pit and reported that cell walls of affected fruit collapse and plasmolyze and pit cavities are formed. Also, Simon, et al. [18] reported that the tissue of bitter-pitted fruits become water-soaked as the external water moves into the free spaces because $\mathrm{Ca}$ is an essential part of the structure of cell walls and the integrity of the cell membrane. Fallahi, et al. [9] described that in addition to bitter pit, fruit Ca status affects certain diseases and firmness of apple fruit tissue, because $\mathrm{Ca}$ is an essential part of the structure of cell walls, and the integrity of the cell membrane. Biochemical processes and enzymatic changes in climacteric fruits such as apples result in the loss of cell wall integrity, leading to the softening and ultimately collapse of fruit tissue [9].

Cell breakdown and browning of the bitter-pitted apple fruit occur largely due to the level of Ca concentration and

*Corresponding author: Esmaeil Fallahi, Department of Plant Sciences, Parma Research and Extension Center, University of Idaho, 29603 U of I Lane, Parma, ID, 83660, USA, Tel: 208-7226701

Accepted: August 25, 2020

Published online: August 27, 2020

Citation: Fallahi E (2020) Phosphite-Based Nutrients Impact Mineral Elements, Bitter Pit, and Fruit Quality Attributes of 'Braeburn' Apple. J Hortic Sci Res 3(1):104-112 
activities of polyphenol oxidase and peroxidase enzymes [1921]. Wang, et al. [20] reported that activities of catalase, peroxidase, ascorbate peroxidase and superoxide dismutase in apple fruit with bitter pit was significantly lower than those without this disorder. Lipoxygenase activity had a negative correlation with fruit $\mathrm{Ca}$ concentration, and thus a positive correlation with occurrence of bitter pit disorder [21-23]. De Freitas, et al. [24] suggested a connection between bitter pit and $\mathrm{Ca}^{2+}$ binding to cell walls as well as accumulation of $\mathrm{Ca}^{2+}$ in storage organelles. They later found an association between higher levels of water-soluble pectin $\mathrm{Ca}^{2+}$ and bitter pit [25].

\section{Impacts of other minerals and their imbalanced ratios to $\mathrm{Ca}$}

Other nutrients associated with bitter pit disorder include N [14,26-31], Mg [4,5,13,26-28,30], phosphorous (P) $[4,28,30,31], K[4,13,26-28,30]$, iron (Fe) [32], zinc (Zn), manganese $(\mathrm{Mn})$, copper $(\mathrm{Cu})[33]$, and boron $(\mathrm{B})[4,30,34]$.

Imbalances between ratios of certain minerals to Ca have a greater impact than merely low levels of $\mathrm{Ca}$ in the occurrence of bitter pit in some apple cultivars. For instance, we have frequently observed imbalances in fruit $\mathrm{K} / \mathrm{Ca}, \mathrm{N} / \mathrm{Ca}$, and $\mathrm{Mg} / \mathrm{Ca}$ ratios in the bitter-pitted fruit of 'Honeycrisp', 'Desert Rose Fuji', 'Autumn Rose Fuji', and 'Starkspur Golden Delicious' apples (Fallahi, et al. unpublished data). Also, Cheng, et al. [11] reported that 'Honeycrisp' apple fruit had lower $\mathrm{Ca}$ and much higher $\mathrm{K} / \mathrm{Ca}$ ratio than 'Gala' apple fruit. The imbalances between ratios of certain minerals to $\mathrm{Ca}$ and their impacts on bitter pit in apples are also reported by other researchers [13,14,26,28,30,35,36]. Ben, et al. [37] reported ratios of $\mathrm{Na} / \mathrm{Ca}, \mathrm{K} / \mathrm{Ca}, \mathrm{P} / \mathrm{Ca}$ and $\mathrm{Mg} / \mathrm{Ca}$ had stronger association with bitter pit disorder than the concentrations of each of these elements by itself. Wińska-Krysiak and Lata, et al. [22] reported that high ratio of $\mathrm{K} / \mathrm{Ca}$ increases the activity of lipoxygenase enzyme in fruits, leading to higher bitter pit disorder.

High fruit $\mathrm{K}$ and $\mathrm{Mg}$ are also believed to increase bitter pit incidence regardless of Ca content [38]. Fallahi, et al. [10] were able to induce severe bitter pit symptoms in 'Golden Delicious' apple fruit by vacuum infiltration of $\mathrm{Mg}$, and thus increasing $\mathrm{Mg} / \mathrm{Ca}$ ratio in the fruit tissue. Baugher, et al. [39] reported a strong correlation between fruit $\mathrm{N} / \mathrm{Ca}$ ratio and bitter pit. They also revealed that peel nutrients had stronger correlations with bitter pit than did the flesh nutrients in 'Honeycrisp' apple. We found that fruit $\mathrm{Ca}$ and $\mathrm{K} / \mathrm{Ca}$ ratio in the calyx end tissue had stronger association with bitter pit than did those in other portions of apple fruit tissues in 'Honeycrisp' apples (Fallahi, et al. data not published).

\section{Calcium spray to reduce bitter pit and improve fruit quality}

Calcium is often considered to be the most important mineral element determining apple fruit quality and reducing metabolic disorders. Foliar sprays can increase the Ca content of apple fruit [40] and firmness [41] and reduce bitter pit and postharvest decay caused by Gloeosporium perennans and Alternaria spp [41,42].

Calcium chloride $\mathrm{Ca}(\mathrm{Cl})_{2}$ sprays are widely used on 'York', 'Fuji', 'Golden Delicious' apples to reduce bitter pit in Pennsylvania orchards [43]. Despite the use of $\mathrm{CaCl}_{2}$ and Calcium nitrate $\left[\mathrm{Ca}\left(\mathrm{NO}_{3}\right)_{2}\right]$ for improving apple fruit quality attributes, application of amino acid, polyamine, and phosphite-based nutrients have become popular in the past decade. "Sysstem" Series products are manufactured by Agri-K Science Driven Nutrition (Minneapolis, MN) and have phosphites leverage which may rapidly penetrate plant vascular tissue and be a vehicle to deliver critical nutrients like $\mathrm{Ca}, \mathrm{Zn}, \mathrm{Mg}, \mathrm{Mn}$, and $\mathrm{K}$ for maximum effect. In this research, the influence of Sysstem nutrients on leaf and fruit mineral status in one season, and fruit bitter pit and quality attributes in two seasons in 'Braeburn' apple was studied.

\section{Materials and Methods}

The experiment was conducted over two seasons in an 18-year-old 'Braeburn' apple orchard, where trees were budded onto M.7 rootstock and planted at $3.05 \mathrm{~m}$ between trees and $5.18 \mathrm{~m}$ between rows in Sunny Slope region of Caldwell, Idaho, U.S.A. The orchard soil was sandy loam with $\mathrm{pH}$ of near 7.5. Two nutritional regimes were applied in this experiment as 1) Grower's nutrients (GS) (Table 1), 2) Sysstem nutrients (Table 2).

Seventeen rows of uniform trees were used for this study in each year. Two guard rows were kept on either side of each experimental row and these guard trees did not receive any nutrient treatments. Thus, we had five experimental rows in each year. In the first year, five adjacent trees with uniform canopy size and crop load on each experimental row were tagged and all five trees received Grower's nutrients, while five uniform trees on 10 trees away on the same row received Sysstem nutrients. In the second year (Year 2), the experimental design was the same as Year 1, except that an additional group of five adjacent trees on each of the experimental row was selected as Un-Treated control (total of three treatments). Therefore, the experimental design was randomized block design with five-tree blocks or replications,

Table 1: Grower's nutrients names, rates, frequencies and times of applications in Years 1 and 2.

\begin{tabular}{|c|c|c|c|c|c|}
\hline Chemical & Rate & Year applied & Application no & Method & Stage applied \\
\hline Ammonium sulfate & $190 \mathrm{~g} /$ tree & Year 1 \& 2 & Once & Ground & dormant \\
\hline Potassium chloride & $454 \mathrm{~g} /$ tree & Year $1 \& 2$ & Once & Ground & dormant \\
\hline Calcium chloride & $4.48 \mathrm{~kg} \cdot \mathrm{ha}^{-1}$ & Year 1 & 3 times & Foliar spray & With 3 cover sprays \\
\hline Amino acid complex $\mathrm{Ca}$ & Label rate & Year 2 & 3 times & Foliar spray & Fruit at $12 \mathrm{~mm} \& 2$ cover sprays \\
\hline Amino acid $\mathrm{B}, \mathrm{Fe}, \mathrm{Zn}, \mathrm{Cu}, \mathrm{MN}$ & Label rate & Year $1 \& 2$ & 3 times & Foliar spray & With 3 cover sprays \\
\hline
\end{tabular}

Each application was made at the rate of 1870 L.ha-1. 
Citation: Fallahi E (2020) Phosphite-Based Nutrients Impact Mineral Elements, Bitter Pit, and Fruit Quality Attributes of 'Braeburn' Apple. J Hortic Sci Res 3(1):104-112

Table 2: Sysstem nutrient regime in Years 1 and 2.

\begin{tabular}{|l|l|l|}
\hline \multicolumn{1}{|c|}{ Product } & \multicolumn{1}{c|}{ Rate } & Time of application \\
\hline Sysstem Zinc & $4.68 \mathrm{~L} / \mathrm{ha}$ & Pre-Pink (Stage 4-5) \\
\hline Sysstem Magnesium & $2.33 \mathrm{~L} / \mathrm{ha}$ & Pre-Pink (Stage 4-5) \\
\hline Boron & At recommended rate & Pink (strong leaf push) \\
\hline $10-45-10$ & $6.72 \mathrm{~kg} / \mathrm{ha}$ & Pink (strong leaf push) \\
\hline Sysstem Cal & $7.01 \mathrm{~L} / \mathrm{ha}$ & $1^{\text {st }}$ Bloom \\
\hline Sysstem Cal & $7.01 \mathrm{~L} / \mathrm{ha}$ & $1^{\text {st }}$ Bloom \\
\hline Symspray 20X & $1.12 \mathrm{~kg} / \mathrm{ha}$ & Petal Fall \\
\hline $10-45-10$ & $6.72 \mathrm{~kg} / \mathrm{ha}$ & Petal Fall \\
\hline Sysstem Cal & $7.01 \mathrm{~L} / \mathrm{ha}$ & $7-10$ Days Post Petal Fall \\
\hline Vigor-Cal & $4.68 \mathrm{~L} / \mathrm{ha}$ & $7-10$ Days Post Petal Fall \\
\hline Symspray 20X & $1.12 \mathrm{~kg} / \mathrm{ha}$ & $7-10$ Days Post Petal Fall \\
\hline $10-45-10$ & $4.48 \mathrm{~kg} / \mathrm{ha}$ & $14-21$ Days Post Petal Fall \\
\hline Vigor-Cal & $4.68 \mathrm{~L} / \mathrm{ha}$ & $14-21$ Days Post Petal Fall \\
\hline Symspray 20X & $1.12 \mathrm{~kg} / \mathrm{ha}$ & $14-21$ Days Post Petal Fall \\
\hline $10-45-10$ & $4.48 \mathrm{~kg} / \mathrm{ha}$ & Repeat every 10 days \\
\hline Vigor-Cal & $4.68 \mathrm{~L} / \mathrm{ha}$ & Beginning July (repeat monthly) \\
\hline KDL & $9.35 \mathrm{~L} / \mathrm{ha}$ & Beginning July (repeat monthly) \\
\hline Symspray 20X & $1.12 \mathrm{~kg} / \mathrm{ha}$ & \\
\hline
\end{tabular}

with two treatments in Year 1 and three treatments in Year 2. In this study, all five trees in each plot received the same treatment or designated as Un-treated Control, but only the middle three trees of each plot were used for data collection and the two outer trees were considered as in-row guard trees. Therefore, we had a total of 15 trees (five blocks $x$ three middle trees) for collecting data in each treatment each year. Other than nutritional treatments, all cultural practices in the Grower's nutrients and Sysstem nutrients were similar to those of commercial orchards in the Pacific Northwest [44].

The three "data trees" in each plot were flagged and used for repeated leaf and fruit samplings in Year 1. Fruits were sampled in September and November. Theses sampling dates in leaf and fruit were chosen because they were considered as critical developmental stages and would unveil a fluctuating pattern that could eventually assist us in finding an optimum time of sampling. Leaf area was measured, and leaf and fruit tissues were immediately analyzed for mineral analyses, similar to the procedures described by Fallahi, et al. [45]. Since the experimental trees were mature with large volume and had high yield in both years, three leaf and two fruit samplings did not have any effects on the final mineral nutrient status or fruit quality attributes in this study.

In early November of each year, 35 fruits per tree were sampled for quality analyses at harvest and after three months of $0{ }^{\circ} \mathrm{C}$ regular atmosphere storage. Bitter pit and quality attributes were measured at the University of Idaho Pomology and Viticulture Laboratory. For quality evaluations, fruits were weighed, and fruit color was visually ranked on a scale of 1 to 5 , with $1=20 \%$ red, progressively to $5=$ $100 \%$ red. Soluble solids concentration (SSC) was measured by temperature-compensated refractometer (Atago N1, To- kyo, Japan). Fruit firmness was measured with a Fruit Texture Analyzer (Guss, Strand, Western Cape, South Africa). Starch degradation pattern (SDP) of equatorial slices of each fruit was recorded by comparison with the SDP standard chart developed for apples. Percentages of fruit with disorders were determined from the collected sub samples at harvest and after storage. The percentage of bitter-pitted fruit was calculated based on number of affected fruits in the sub-samples as well as a percentage of affected fruit in the entire tree. To estimate the percentage of bitter pit in the entire tree, the actual numbers of infected and healthy fruits in two major limbs per tree were counted. In this article, percentage of bitter pit based on the entire tree is reported. Generally, methodologies for fruit quality measurements were accordingly to the procedures described by Fallahi, et al. [45]. Data was analyzed using SAS statistical packages and means were separated according to Fisher Protected Least Significant Differences (LSD) at $5 \%$ level.

\section{Results and Discussions}

\section{General trends in mineral nutrients}

In general, leaf concentrations of $\mathrm{N}, \mathrm{K}, \mathrm{Zn}, \mathrm{Cu}$, and $\mathrm{B}$ declined but $\mathrm{Ca}$ and $\mathrm{Mn}$ increased, and $\mathrm{P}, \mathrm{Mg}, \mathrm{S}$, and Fe remained approximately the same as the growing season progressed in both Grower's nutrients and Sysstem nutrients in Year 1 (Table 3 and Table 4). Based on this study, late-July to early August would be an optimum period for leaf sampling as most mineral elements seemed to be at the "minimal flux" stage (Table 3 and Table 4).

\section{Leaf and fruit minerals concentrations}

Trees receiving Sysstem treatment had lower leaf $\mathrm{N}, \mathrm{P}$, 
Citation: Fallahi E (2020) Phosphite-Based Nutrients Impact Mineral Elements, Bitter Pit, and Fruit Quality Attributes of 'Braeburn' Apple. J Hortic Sci Res 3(1):104-112

Table 3: 'Braeburn' apple leaf macro-elements during the growing season (July-November) in Year $1^{2}$.

\begin{tabular}{|c|c|c|c|c|c|c|c|c|c|c|c|c|c|c|c|c|c|c|}
\hline \multirow[b]{2}{*}{$\begin{array}{l}\text { Nutrient } \\
\text { regime }\end{array}$} & \multicolumn{3}{|c|}{$\mathbf{N}(\% \mathrm{dwt})$} & \multicolumn{3}{|c|}{$P(\% d w t)$} & \multicolumn{3}{|c|}{$K(\%$ dwt) } & \multicolumn{3}{|c|}{ Ca (\% dwt) } & \multicolumn{3}{|c|}{$M g(\% d w t)$} & \multicolumn{3}{|c|}{$S(\% d w t)$} \\
\hline & $\begin{array}{l}\text { July } \\
3\end{array}$ & Sep & $\begin{array}{l}\text { Nov } \\
4\end{array}$ & y 3 & Sep 9 & Nov 4 & $\begin{array}{l}\text { July } \\
3\end{array}$ & $\begin{array}{l}\text { Sep } \\
9\end{array}$ & $\begin{array}{l}\text { Nov } \\
4\end{array}$ & $\begin{array}{l}\text { July } \\
3\end{array}$ & $\begin{array}{l}\text { Sep } \\
9\end{array}$ & $\begin{array}{l}\text { Nov } \\
4\end{array}$ & 3 & Sep 9 & Nov 4 & July 3 & Sep 9 & Nov 4 \\
\hline & $2.4 a$ & 20 & 1. & $9 a$ & $0.64 a$ & $8 a$ & $2.5 a$ & $2.0 a$ & a & $0.9 a$ & $1.5 a$ & 7a & b & b & & $3 a$ & 0.1 & $0.14 a$ \\
\hline ysstem & D. & $2.1 \mathrm{a}$ & & $0.43 a$ & $0.42 b$ & $0.30 \mathrm{~b}$ & $2.1 \mathrm{~b}$ & $1.5 b$ & $1.0 \mathrm{~b}$ & $1.0 \mathrm{a}$ & $1.5 a$ & $1.7 a$ & $0.27 a$ & $0.29 a$ & $0.27 a$ & $0.13 a$ & $0.14 a$ & $0.13 a$ \\
\hline
\end{tabular}

${ }^{2}$ Mean separation within columns by LSD at 0.05 levels.

Table 4: 'Braeburn' apple leaf micro-elements during the growing season (July-November) in Year $1^{2}$.

\begin{tabular}{|l|l|l|l|l|l|l|l|l|l|l|l|l|l|l|l|l|}
\hline & \multicolumn{3}{|c|}{ Mn (ppm) } & \multicolumn{3}{c|}{ Fe (ppm) } & \multicolumn{3}{c|}{ Zn (ppm) } & \multicolumn{3}{c|}{ Cu (ppm) } & \multicolumn{3}{c|}{ B (ppm) } \\
\hline $\begin{array}{l}\text { Nutrient } \\
\text { regime }\end{array}$ & July 3 & Sep 9 & Nov 4 & July 3 & Sep 9 & Nov 4 & July 3 & Sep 9 & Nov 4 & July 3 & Sep 9 & Nov 4 & July 3 & Sep 9 & Nov 4 \\
\hline Grower's & $28 a$ & $42 a$ & $43 a$ & $89 b$ & $114.8 a$ & $120 a$ & $12 a$ & $11 b$ & $10 a$ & $8.7 a$ & $10.0 a$ & $6.3 a$ & $62 a$ & $41 a$ & $34 a$ \\
\hline Sysstem & $25 a$ & $31 b$ & $38 a$ & $112 a$ & $118.8 a$ & $128 a$ & $14 a$ & $13 a$ & $13 a$ & $9.0 a$ & $8.3 b$ & $5.4 a$ & $58 b$ & $34 b$ & $32 a$ \\
\hline
\end{tabular}

${ }^{2}$ Mean separation within columns by LSD at 0.05 levels.

Table 5: 'Braeburn' apple fruit macro-elements during the growing season (September-November) in Year $1^{z}$.

\begin{tabular}{|c|c|c|c|c|c|c|c|c|c|c|c|c|c|c|c|c|c|c|}
\hline & \multicolumn{2}{|c|}{$\begin{array}{c}\mathbf{N} \\
(\mathrm{mg} / 100 \mathrm{~g})\end{array}$} & \multicolumn{2}{|c|}{$\begin{array}{c}\mathbf{P} \\
(\mathrm{mg} / 100 \mathrm{~g})\end{array}$} & \multicolumn{2}{|c|}{$\begin{array}{c}\mathbf{K} \\
(\mathrm{mg} / 100 \mathrm{~g})\end{array}$} & \multicolumn{2}{|c|}{$\begin{array}{c}\mathrm{Ca} \\
(\mathrm{mg} / 100 \mathrm{~g})\end{array}$} & \multicolumn{2}{|c|}{$\begin{array}{c}\mathrm{Mn} \\
(\mathrm{mg} / 100 \mathrm{~g})\end{array}$} & \multicolumn{2}{|c|}{$\begin{array}{c}\mathbf{S} \\
(\mathrm{mg} / 100 \mathrm{~g})\end{array}$} & \multicolumn{2}{|c|}{$\begin{array}{c}\text { N/Ca (mg/ } \\
\mathrm{mg})\end{array}$} & \multicolumn{2}{|c|}{$\begin{array}{c}\text { K/Ca (mg/ } \\
\mathrm{mg})\end{array}$} & \multicolumn{2}{|c|}{$\begin{array}{l}\mathrm{K}+\mathrm{Mg}) / \mathrm{Ca} \\
(\mathrm{mg} / \mathrm{mg})\end{array}$} \\
\hline & 5 & & & & & & & & & & & & & & & & & \\
\hline & & & & & & & & & & & & & & & & & & \\
\hline (1) & $23.3 a$ & 23.8a & $10.8 a$ & 13.5a & $93.4 \mathrm{~b}$ & 105.3D & $4.8 \mathrm{a}$ & $3.5 a$ & $4.5 a$ & $4.4 a$ & $1.6 a$ & 1.00 & $3.0 d$ & 7.0a & $19.8 b$ & $3 \perp 0$ & $20.7 b$ & $32 . \angle \mathrm{N}$ \\
\hline
\end{tabular}

${ }^{2}$ Mean separation within columns by LSD at 0.05 levels.

Table 6: 'Braeburn' apple fruit micro-elements during the growing season (September-November) in Year $1^{2}$.

\begin{tabular}{|l|l|l|l|l|l|l|l|l|l|l|}
\hline & \multicolumn{3}{|c|}{ Mn (ppm) } & \multicolumn{3}{c|}{ Fe (ppm) } & \multicolumn{3}{c|}{ Zn (ppm) } & \multicolumn{3}{c|}{ Cu (ppm) } & \multicolumn{1}{c|}{ B (ppm) } \\
\hline Nutrient regime & Sep 9 & Nov 4 & Sep 9 & Nov 4 & Sep 9 & Nov 4 & Sep 9 & Nov 4 & Sep 9 & Nov 4 \\
\hline Grower's & $0.01 a$ & $0.02 a$ & $0.10 a$ & $0.03 b$ & $0.02 a$ & $0.01 a$ & $0.07 a$ & $0.04 a$ & $0.25 a$ & $0.31 a$ \\
\hline Sysstem & $0.01 a$ & $0.02 a$ & $0.10 a$ & $0.06 a$ & $0.02 a$ & $0.01 a$ & $0.06 a$ & $0.04 a$ & $0.26 a$ & $0.30 a$ \\
\hline
\end{tabular}

${ }^{2}$ Mean separation within columns by LSD at 0.05 levels.

$\mathrm{K}$, and $\mathrm{B}$ but higher leaf $\mathrm{Mg}, \mathrm{Fe}$ and $\mathrm{Zn}$ than those receiving Grower's nutrients during sampling dates in Year 1 (Table 3 and Table 4). Trees with Grower's nutrients were more vigorous (Data not shown) perhaps because of their higher $\mathrm{N}$ uptake (Table 3), leading to higher transpiration and thus uptake. Trees with Sysstem nutrients had larger leaves (data not shown), perhaps due to their higher $\mathrm{Zn}$ and Mg concentrations. Larger leaves can reduce blank wood, and higher leaf $\mathrm{Mg}$ may increase chlorophyll content, resulting in production of more carbohydrate [45]. Improvement in the leaf Fe uptake in the trees with Sysstem nutrients may also increase photosynthetic metabolites.

Trees receiving Sysstem treatment had higher fruit $\mathrm{Ca}$ (up to 12\%) during all sampling dates (Table 5) and fruit iron $(100 \%)$ in November (Table 6) but lower fruit K (up to $9.8 \%$ ), and fruit S (up to 44\%) in September and November (Table 5). Fruit $\mathrm{K} / \mathrm{Ca}$ and $(\mathrm{K}+\mathrm{Mg}) / \mathrm{Ca}$ ratios in November were greater than those in September in both treatments (Table 5). Sysstem nutrients applications improved fruit N/Ca ratio by up to $16 \%, \mathrm{~K} / \mathrm{Ca}$ ratio by $20 \%$, and $(\mathrm{K}+\mathrm{Mg}) / \mathrm{Ca}$ ratio by about $21 \%$ over the Grower nutrients (Table 5). Based on author's personal experience, N/Ca ratio between 4 to 9 is considered normal and ratios above 10 may result in reduction of fruit firmness. In this study, N/Ca did not exceed this optimum range (Table 5). Nevertheless, fruit $(\mathrm{K}+\mathrm{Mg}) / \mathrm{Ca}$ ratio must remain between 10 to 30 . For sensitive cultivars, fruit $(K+M g) /$ Ca ratios exceeding 25 to 30 is alarming as values above these ranges may increase the chance of bitter pit incidence. In this study, application of Sysstem nutrients kept these values at significantly lower levels than those of Grower's nutrients (Table 5), resulting in significantly lower bitter pit incidence at harvest and after storage (Table 7, Table 8 and Table 9).

\section{Impacts on fruit quality attributes}

Major differences existed in some quality attributes between the fruits from Growers nutrients and Sysstem treatments in both years (Table 7, Table 8 and Table 9). Fruits from the Sysstem-treated trees had better color, more soluble solids concentration (SSC), more starch degradation pattern 
Citation: Fallahi E (2020) Phosphite-Based Nutrients Impact Mineral Elements, Bitter Pit, and Fruit Quality Attributes of 'Braeburn' Apple. J Hortic Sci Res 3(1):104-112

Table 7: 'Braeburn' apple fruit quality attributes at harvest in Year $1^{2}$

\begin{tabular}{|l|c|l|l|l|l|l|l|l|l|l|l|l|}
\hline $\begin{array}{l}\text { Nutrient } \\
\text { regime }\end{array}$ & $\begin{array}{c}\text { Weight } \\
(\mathrm{g})\end{array}$ & $\begin{array}{c}\text { Color } \\
(1-5)^{2}\end{array}$ & $\begin{array}{c}\text { Soluble } \\
\text { solids } \\
\left({ }^{\circ} \text { Brix) }\right.\end{array}$ & $\begin{array}{c}\text { Firmness } \\
(\mathrm{N})\end{array}$ & $\begin{array}{c}\text { Starch } \\
\text { pattern } \\
(1-6)^{2}\end{array}$ & $\begin{array}{c}\text { Bitter pit } \\
(\%)\end{array}$ & $\begin{array}{c}\text { Sunburn } \\
(\%)\end{array}$ & $\begin{array}{c}\text { Water } \\
\text { core (\%) }\end{array}$ & $\begin{array}{c}\text { Russet } \\
(\%)\end{array}$ & $\begin{array}{c}\text { Pale } \\
\text { spot (\%) }\end{array}$ & $\begin{array}{c}\text { Green } \\
\text { stain (\%) }\end{array}$ & $\begin{array}{c}\text { Crack } \\
(\%)\end{array}$ \\
\hline Grower's & $180.4 \mathrm{a}$ & $3.40 \mathrm{~b}$ & $10.9 \mathrm{~b}$ & $85.7 \mathrm{a}$ & $3.16 \mathrm{~b}$ & $7.24 \mathrm{a}$ & $10.7 \mathrm{a}$ & $7.5 \mathrm{a}$ & $5.9 \mathrm{a}$ & $0.67 \mathrm{~b}$ & $0.67 \mathrm{a}$ & $0.67 \mathrm{a}$ \\
\hline Sysstem & $174.0 \mathrm{a}$ & $4.55 \mathrm{a}$ & $11.5 \mathrm{a}$ & $83.8 \mathrm{a}$ & $3.97 \mathrm{a}$ & $0.67 \mathrm{~b}$ & $5.5 \mathrm{~b}$ & $5.0 \mathrm{a}$ & $6.8 \mathrm{a}$ & $4.02 \mathrm{a}$ & $1.36 \mathrm{a}$ & $0.01 \mathrm{a}$ \\
\hline
\end{tabular}

${ }^{2}$ Mean separation within columns by LSD at 0.05 levels.

Abbreviations: Color scales: $1=$ green, progressively to $5=$ red, Starch degradation pattern (SDP) was ranked from $1=$ very starchy to $6=$ most mature fruit.

Table 8: Fruit quality attributes of 'Braeburn' apple after storage Year $1^{2}$.

\begin{tabular}{|c|c|c|c|c|c|c|c|c|c|c|c|c|c|}
\hline Nutr & $\begin{array}{c}\text { Weight } \\
\text { (g) }\end{array}$ & $\begin{array}{l}\text { Weigh } \\
\text { loss (\%) }\end{array}$ & $\begin{array}{l}\text { Color } \\
(1-5)\end{array}$ & $\begin{array}{l}\text { Sugar } \\
\text { ('Brix) }\end{array}$ & $\begin{array}{c}\text { Firmness } \\
\text { (N) }\end{array}$ & $\begin{array}{c}\text { Starch } \\
(1-6)\end{array}$ & $\begin{array}{c}\text { Bitter pit } \\
(\%)\end{array}$ & $\begin{array}{c}\text { Sunburn } \\
(\%)\end{array}$ & $\begin{array}{l}\text { W } \\
\text { cor }\end{array}$ & $\begin{array}{c}\text { Russet } \\
(\%)\end{array}$ & $\begin{array}{r}\mathrm{Pa} \\
\text { spot }\end{array}$ & $\begin{array}{c}\text { Green stain } \\
(\%)\end{array}$ & $\begin{array}{c}\text { Scald } \\
(\%)\end{array}$ \\
\hline & 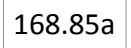 & & & 1 & & & & & & & & & \\
\hline & $8.77 a$ & $.0 \mathrm{~b}$ & $55 a$ & $2.04 a$ & $.1 a$ & .40 & $86 b$ & 3.77a & 15.00a & .41 & & & $0.91 a$ \\
\hline
\end{tabular}

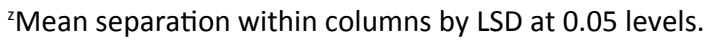

Abbreviations: Color scales: $1=$ green, progressively to $5=$ red; Starch degradation pattern (SDP) was ranked from $1=$ very starchy to $6=$ most mature fruit.

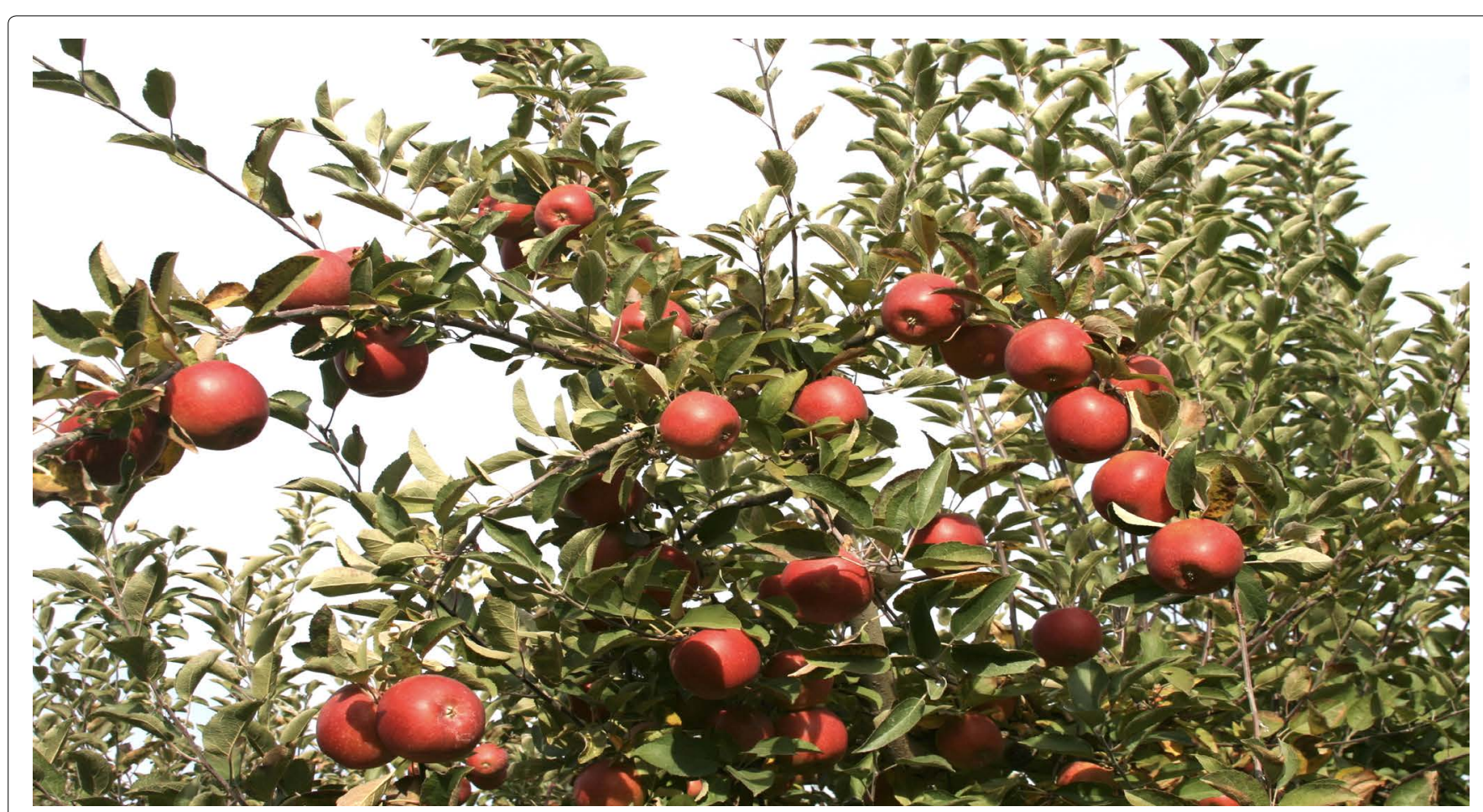

Figure 1: 'Braeburn' apples with Sysstem nutrients had lower bitter pit in Years $1 \& 2$.

(SDP), and lower bitter pit, sunburn, and "pale spot" than those from Grower's nutrients at harvest in Year 1 (Table 7) (Figure 1, Figure 2 and Figure 3). No difference was observed in SDP after the storage in Year 1 (Table 8). Otherwise, the pattern in treatment differences after storage was similar to those at harvest in first year.

The bitter pit difference between nutrient treatments after storage was greater than that at harvest in the first year (Table 7 and Table 8). Water core and SSC of both treatments were greater after storage compared to harvest time (Table
7 and Table 8), indicating that fruit ripened and reached or passed climacteric peak in the storage. Post-storage weight loss in the fruit from trees receiving Sysstem treatments was significantly (about $53 \%$ ) less than those receiving Grower's Nutrients treatments (Table 8).

Significant reduction in fruit weight loss, bitter pit and "pale spot" (Figure 3) has a major impact to commercial apple growers as improvement in these quality attributes would lead to a higher pack-out and more net profit.

In Year 2, trees receiving Sysstem treatments had higher 


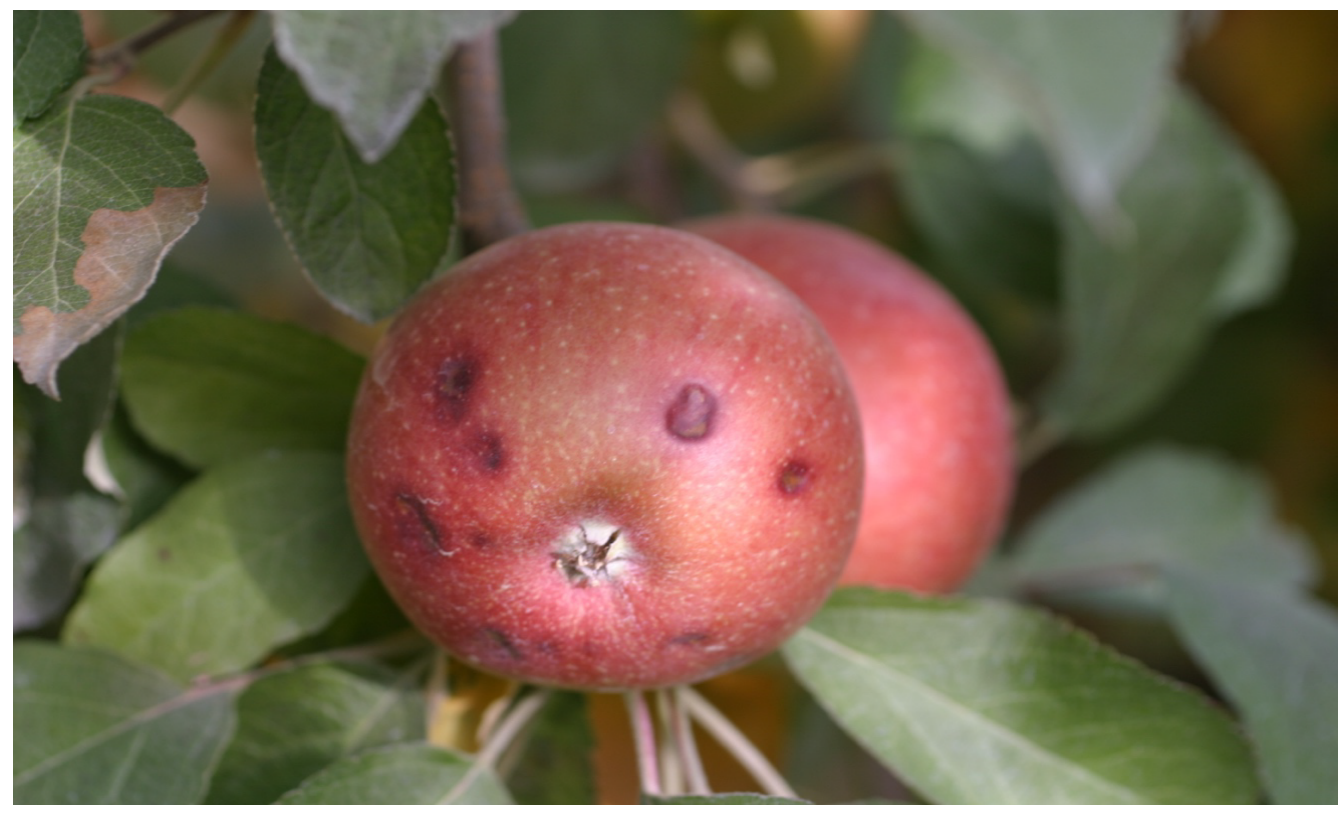

Figure 2: 'Braeburn' apples with Grower's nutrients had more bitter pit in both years.

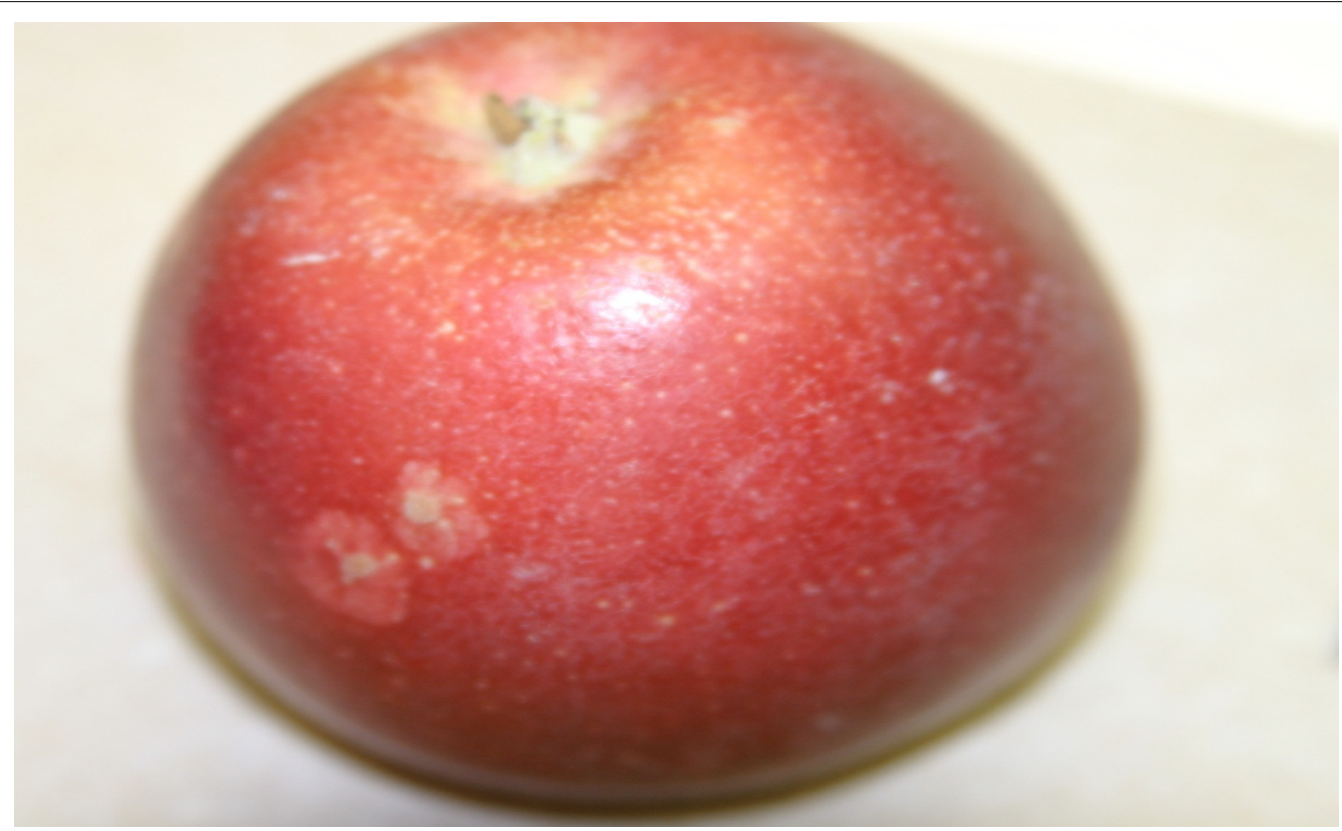

Figure 3: Pale spots were more severe in fruit with Grower's nutrients.

fruit size, color, and yield per tree but lower fruit water core, sunburn, russet, bitter pit, cracking, and internal browning than those receiving Grower's nutrients, although differences were not always significant (Table 9).

We believe that better quality attributes in the Sysstem-treated trees could be due to the better absorption of some essential nutrients and the lower $\mathrm{N}$ in their leaves as reported earlier [8]. Leaf area of trees with Sysstem nutrients was slightly increased during some sampling dates (data not shown). This factor, in addition to an improvement in $\mathrm{Mg}$, Fe, and $\mathrm{Zn}$ accumulation in the leaves of Sysstem-treated trees could have contributed to an improved photosynthesis and thus better fruit quality in these trees. Sysstem nutrients improved fruit $\mathrm{Ca}, \mathrm{K} / \mathrm{Ca}$ and $\mathrm{N} / \mathrm{Ca}$ ratios and these improvements could have contributed to a significantly lower bitter pit and better color in the fruit from Sysstem-treated trees. Detail photosynthetic activities and carbohydrate partitioning after application of Sysstem nutrients and other nutrient regimes deserves further study.

Perhaps the most important impact of Sysstem regime is its reduction of fruit bitter pit incidence. 'Braeburn', 'Honeycrisp', and 'Golden Delicious' apples are among the most sensitive apple cultivars to bitter pit. When compared to Grower's nutrients, Sysstem treatments reduced bitter pit incidence by about $91 \%$ at harvest and by $87 \%$ after storage in Year 1 (Table 7 and Table 8 ) and by $26 \%$ at harvest and $60 \%$ after har- 
vest in Year 2 (Table 9). In Year 2, fruit from un-treated control trees had lower bitter pit than trees receiving Growers nutrient because they had smaller size, leading to higher fruit Ca concentration, which is consistent with a previous report in 'Spark Spur Golden Delicious' apple [38].

Based on author's observations and experience with different apple cultivars, the formulation of the calcium and windows of applications are crucial to uptake and performance, while the cost of chemical also plays an important role in a sustainable production system. Thus, apple growers need to emphasize on supplying Ca during and after fruit cell division stages and use various formulations of $\mathrm{Ca}$ as tools in the toolbox and pick the best one for each timing, variety and purpose. Application of $\mathrm{Ca}$ in a phophite formulation at certain stage of apple development could be more advantages over the nitrate and chloride forms. In addition to be an effective source of $\mathrm{Ca}$, the phosphite portion of calcium phosphite formulation (Sysstem Cal, Sysstem SeaCal) may have an impact on the reduction of phythophora (Phytophthora spp.) and fire blight (Erwinia amylovora), although this aspect of phosphite potential impacts requires further studies. In some modern orchards, growers use a multiple-tool approach to control Ca-related issues such as bitter pit. In these orchards, foliar anti-bitter pit programs could start with Sysstem Cal as the Ca source and then moves to Vigor Cal (a dextrose-lactose formulation) that has efficient uptake and safety like the amino acid (Metalosate) formulations but at a lower cost than amino acid or than phosphite. During the mid-season, foliar application Vigor Cal can supply Ca to the trees, with or without growth regulator Apogee, and without having the potential negative impacts of calcium nitrate $\left[\mathrm{Ca}\left(\mathrm{NO}_{3}\right)_{2}\right]$. Calcium nitrate increases $\mathrm{Ca}$ uptake, but negatively impacts the fruit N/Ca ratio because its nitrate can promote bitter pit, reduce fruit color, firmness and storability. The nitrate form of $\mathrm{Ca}\left(\mathrm{NO}_{3}\right)_{2}$ may also promote fire blight and in some cases powdery mildew (Podosphaera leucotricha) diseases. Foliar calcium chloride $\left(\mathrm{CaCl}_{2}\right)$ is well documented to be an effective and inexpensive source of $\mathrm{Ca}$ [42]. However, frequent applications of $\mathrm{CaCl}_{2}$ throughout the season in the western United States will induce stress. Thus, limiting the number of applications of $\mathrm{CaCl}_{2}$ and delaying the starting dates for application may be a better strategy.

\section{Conclusions and Recommendations}

In our study, phosphite-based nutrients appeared to show promising results by reducing bitter pit and improving fruit quality attributes at harvest and after storage. Ratio of fruit minerals, especially $\mathrm{K} / \mathrm{Ca}$ and $(\mathrm{K}+\mathrm{Mg}) / \mathrm{Ca}$, are extremely crucial in predicting bitter pit occurrence. Despite our promising results, the following studies are recommended to understand the efficiency and cost of applications of nutrient products under high density systems with modern tree canopy architectures and rootstocks: 1) Application of Phosphite formulation during early growing season, followed by Vigor Cal in the middle season; 2) Early season applications of $\mathrm{Ca}$ ($\left.\mathrm{NO}_{3}\right)_{2}$ and $\mathrm{CaCl}_{2}$ followed by late applications of Sysstem nutrients; 3) Comparing amino acid-based and phosphite-based nutrients in each region; 4) Studying the impacts of nutrients 
Citation: Fallahi E (2020) Phosphite-Based Nutrients Impact Mineral Elements, Bitter Pit, and Fruit Quality Attributes of 'Braeburn' Apple. J Hortic Sci Res 3(1):104-112

on storage scalds and other disorders [46] and possible interactions of bioregulators such as prohexadione and GA (4+ 7), combined with nutrient on bitter pit [47] and fruit quality attributes after storage.

\section{Acknowledgement}

We thank the Idaho Apple Commission and the Idaho Agricultural Experiment Station for their financial support of this project. This work was supported in part by U.S. Department of Agriculture National Institute of Food and Agriculture Specialty Crop Research Initiative project "Apple Root2 Fruit: Accelerating the development, evaluation and adoption of new apple rootstocks" (2016-51181-25406). The author wishes to express his gratitude to the utmost professionalism and financial support of Agro-K Science-Driven Nutrition, Minneapolis, MN and for the material and labor support by Symms Fruit Ranch, Caldwell, Idaho in this study. The author is also thankful to all scientists and technicians in the University of Idaho Pomology and Viticulture Program who assisted us in different aspects of this research project.

\section{References}

1. DeLong WA (1936) Variations in the chief ash constituents of apples affected with blotchy cork. Plant Physiol 11: 453-456.

2. Smock RM (1941) Studies on bitter pit of apples. Cornell University, Agri Exp Station, Memoir.

3. Garman P, Mathis WT (1956) Studies of mineral balance as related to occurrence of Baldwin spot in Connecticut. Conn Agr Expt Sta 601: 5-19.

4. Shear CB (1975) Calcium-related disorders of fruits and vegetables. Hort Science 10: 361-365.

5. Hopfinger JA (1978) Physiological role of calcium and magnesium in the development of bitter pit in 'Golden Delicious' apples. PhD Thesis. Washington State University, Pullman, Washington.

6. Horn AS (1975) Bitter pit of apples. University of Idaho, Cooperative Extension Service.

7. Rosenberger DA, Schupp JR, Watkins CB, et al. (2004) Controlling bitter pit in 'Honeycrisp' apples. Hort Technology 14: 342-349.

8. Fallahi E, Richardson DG, Westwood MN, et al. (1985) Relationship among mineral nutrition, ethylene and post-harvest physiology in apples on six rootstocks. Scientia Horticulturae 25: 163175.

9. Fallahi E, Conway WC, Hickey KD, et al. (1997) The role of calcium and nitrogen in postharvest quality and disease resistance of apples. Hort Science 32: 831-835.

10. Fallahi E, Righetti TL, Wernz JG (1987) Effects of dip and vacuum infiltration of various inorganic chemicals on postharvest quality of apple. Commun Soil Sci Plant Anal 18: 1018-1029.

11. http://www.hort.cornell.edu/expo/proceedings/2016/ TreeFruit.\%20Challenged\%20and\%20opportunities\%20to\%20optimize\%20mineral\%20nutrition\%20of\%20Honeycrisp.Cheng.pdf

12. Kalcsits LG, Heijden VD, Reid M, et al. (2017) Calcium absorption during fruit development in 'Honeycrisp' apple measured Using ${ }^{44} \mathrm{Ca}$ as a stable Isotope tracer. Hort Science 52: 1804-1809.

13. Perring MA (1968) Mineral compositions of apples VIII-The relationship between composition and disorders of the fruit. J Sci Fd Agric 19: 186-192.
14. Raese JT (1988) Calcium: Effects on apple and pear disorders and fruit quality. Wash St, Hort Assn Proc, 84th Annual Meeting. 247257.

15. Crassweller RM, Marini RP, Baugher TA, et al. (2019) Five-year nutritional study of apples in commercial high-density orchards. Acta Hortic 1253: 163-168.

16. Wilkinson BG (1968) Mineral composition of apples IX-Uptake of calcium by the fruit. J Sci Fd Agric 19: 646-647.

17. Smock RM, Van Doren A (1937) The history of bitter pit in apples. Proc Am Soc Hort Sci 35: 176-179.

18. Simon EW (1978) The symptoms of calcium deficiency in plants. New phytol 80: 1-15.

19. Napier D, Combrink N (2006) Aspects of calcium nutrition to limit plant physiological disorders. V Int Pineapple Symp 702: 107116.

20. Wang L, Jiang W, He Z, et al. (2001) Studies on the relationship of the development of bitter pit in apple fruits with the contents of calcium and magnesium and the activities of antioxidant enzymes. Acta Hort 28: 200-205.

21. Sharma R, Pal R, Singh D, et al. (2012) Relationships between storage disorders and fruit calcium contents, lipoxygenase activity, and rates of ethylene evolution and respiration in 'Royal Delicious' apple (Malus $x$ domestica Borkh.). J Hortic Sci Biotechnol 87: 367-373.

22. Wińska-Krysiak M, Lata B (2010) Influence of lipoxygenase activity and calcium and potassium contents on bitter pit occurrence in commercial apple cultivars. Folia Hortic 22: 13-17.

23. Jemrić T, Fruk I, Fruk M, et al. (2016) Bitter pit in apples: pre- and postharvest factors: A Review. Spanish J Agri Res 14: 1-12.

24. De Freitas ST, do Amarante CVT, Labavitch JM, et al. (2010) Cellular approach to understand bitter pit development in apple fruit. Postharvest Biol Technol 57: 6-13.

25. De Freitas ST, do Amarante CVT, Mitcham EJ (2015) Mechanisms regulating apple cultivar susceptibility to bitter pit. Sci Hort 186: 54-60.

26. Faust M, Shear CB (1968) Corking disorders of apples: A physiological and biochemical review. Bot Rev 34: 441-469.

27. Pierson CF, Ceponis MJ, McColloch LP (1971) Market diseases of apples, pears, and quinces. US Dept. of Agriculture Handbook 376, Washington DC.

28. Mielke EA, Facteau TJ (1988) An overview of calcium and it's interactions in fruit trees. Wash St Hort Assn Proc, 84th Annual Meeting, 236-246.

29. Raese JT (1989) Calcium's effect on bitter pit and fruit quality in 'Red Delicious' and 'Golden Delicious' apples. Good Fruit Grower 1: 37-41.

30. Raese JT (1989) Important considerations about calcium on apples and pears. Good Fruit Grower 1: 32-35.

31. Recasens I, Benavides A, Puy J, et al. (2004) Pre-harvest calcium treatments in relation to the respiration rate and ethylene production of 'Golden Smoothee' apples. J Sci Food Agric 84: 765771.

32. Robinson T, Lopez S (2012) Crop load affects 'Honeycrisp' fruit quality more than nitrogen, potassium, or irrigation. Acta Hortic 940: 529-537.

33. Sanz M, Machín J (1999) Applying floral analysis for the progno- 
sis and diagnosis of bitter pit. ITEA (Agricultural Economic Technical Information). Vegetable Production (Spain) 95: 118-124.

34. Liu H, Han Z (1997) Apple fruit mineral nutrition. J Fruit Sci. 14: 73-78.

35. Wójcik P, Mika A (1996) Effect of fertilization of apple trees with boron on the growth, yield and fruit quality. Zeszyty Problemowe Postepow Nauk Rolniczych 434: 419-424.

36. Drake M, Bramlage WJ, Baker JH (1974) Correlations of calcium content of 'Baldwin' apples with leaf calcium, tree yield, and occurrences of physiological disorders and decay. J Amer Soc Hor Sci 99: 379-380.

37. Ben J (1998) Estimation of apple storage quality based on fruit analysis. Int Sem: Ecological Aspects of Nutrition and Alternatives for Herbicides in Horticulture. Warszawa, Poland 7-8.

38. Krishkov E (2007) Factors influencing the incidence of bitter pit on apple fruits and control measures. Agricultural Science 40: 22-26.

39. Baugher TA, Marini R, Schupp JR, et al. (2017) Prediction of bitter Pit in 'Honeycrisp' apples and best management implications. Hortscience 52: 1368-1374.

40. Drake M, Bramlage WJ, Baker JH (1979) Effects of foliar calcium on McIntosh apples storage disorders. Communications in Soi Science and Plant Analysis 10: 303-309.
41. Sharples RO, Johnson DS (1977) The influence of calcium on senescence changes in apples. Ann Appl Biol 85: 450-453.

42. Biggs AR, Ingle M, Solihati WD (1993) Control of Alternaria infection of fruit of apple cultivar 'Nittany' with calcium chloride and fungicides. Plant Disease 77: 976-980.

43. Hickey KD, Conway WS, Sams CE (1995) Effect of calcium sprays and cultivar resistance on fruit decay development on apple. Pennsylvania Fruit News 75: 37-40.

44. http://www.tfrec.wsu.edu

45. Fallahi E, Arzani K, Fallahi B (2013) Long-term leaf mineral nutrition in 'Pacific Gala' apple (Malus $x$ domestica Borkh.) as affected by rootstock, type and irrigation system during six stages of tree development. The Journal of Horticultural Science and Biotechnology 88: 685-692.

46. https://pennstate.pure.elsevier.com/en/publications/bitter-pitand-soft-scald-development-during-storage-of-unconditi

47. Do Amarante CVT, Silveiraa JPG, Steffensa CA, et al. (2020) Postbloom and preharvest treatment of 'Braeburn' apple trees with prohexadione calcium and $\mathrm{GA}_{4+7}$ affects vegetative growth and postharvest incidence of calcium related physiological disorders and decay in the fruit. Scientia Horticulturae 261: 1-9.

\section{DOI: $10.36959 / 745 / 405$}

